\title{
Water management for wheat grown in sandy soil under climate change conditions
}

\author{
M.M. Ibrahim ${ }^{1, *}$, S.A. Ouda ${ }^{2}$, A. Taha ${ }^{2}$, G. El Afandi ${ }^{3}$ and S.M. Eid ${ }^{2}$ \\ ${ }^{I}$ Soil \& water Dept. Fac.of Agric. Univ. of Tanta, Egypt. ${ }^{2}$ Soils, Water, and Environment Research Institute, \\ A.R.C., Giza, Egypt. ${ }^{3}$ Dept. of Astronomy and Meteorology; Fac. of science; Al Azhar Univ., Egypt. \\ *Corresponding author: mahmoudibrahim421@yahoo.com
}

\begin{abstract}
The effect of fertigation regimes on wheat grown in sandy soil was tested in two field experiments in Egypt. The aim of the study was to determine the vulnerability of wheat to extreme weather event under climate change scenarios. Eight fertigation treatments, in addition to farmer irrigation were tested. Two climate change scenarios obtained from Hadley climate change model were incorporated in CropSyst model to assess wheat yield responses to fertigation regimes under these scenarios. The results showed that the highest yield and the highest water use efficiency (WUE) was obtained under irrigation application using 1.2 and 0.8 of Etc, respectively, with fertigation application in $80 \%$ of application time in both growing seasons. The calibration of CropSyst model confirmed that the model is able to mimic the growth of wheat and predicted grain, biological yield, and WUE with high degree of accuracy. The highest yield reduction and the lowest WUE under the tested climate change scenarios were obtained from farmer irrigation. It can be concluded that irrigating wheat grown in sandy soil with an amount of either 1.0 or 0.8 of ETc with fertigation application in $80 \%$ of application time is recommended to enhance growth and yield, and to reduce wheat's damage caused by extreme climate change.
\end{abstract}

Keywords: fertigation, wheat, sandy soil, CropSyst model, Hadley model, climate change scenarios. 


\section{Introduction}

The Earth has warmed by $0.7^{\circ} \mathrm{C}$ on average since 1900. Most of the warming since 1950 is due to human activities that have increased greenhouse gases (IPCC, 2001). There has been an increase in heat waves, fewer frosts, warming of the lower atmosphere and Upper Ocean, retreat of glaciers and sea-ice, an average rise in global sea-level of approximately 17 $\mathrm{cm}$ and increased heavy rainfall in many regions. Many species of plants and animals have changed their location or behavior in ways that provide further evidence of global warming (IPCC, 2001).

To estimate future climate change, scientists have developed greenhouse gas and aerosol emission scenarios for the $21^{\text {st }}$ century. These are not predictions of what will actually happen. They allow analysis of "what if?" questions based on various assumptions about human behavior, economic growth and technological change (Church and White, 2006). Computer models of the climate system are the best tools available for simulating climate variability and change. These models include representations of the atmosphere, oceans, biosphere and Polar Regions. Confidence in the reliability of these models for climate projections has also improved (IPCC, 2001), based on tests of the ability to simulate the present average climate, including the annual cycle of seasonal changes, year-to-year variability, extreme events, such as storms and heat waves, climates from thousands of years ago, and observed climate trends in the recent past. The IPCC attributes most of the global warming observed per the last 50 years to greenhouse gases released by human activities. To estimate future climate change, the IPCC prepared forty greenhouse gas and sulfate aerosol emission scenarios for the $21^{\text {st }}$ century that combine a variety of assumptions about demo- graphic, economic and technological driving forces likely to influence such emissions in the future. Climate change as projected by these climate models has the potential to significantly alter the conditions for crop production, with important implications for worldwide food security. Many studies have documented the effects of climate change on wheat yield in Egypt and concluded that the yield could be reduced by an average of $30 \%$ in the Nile Delta and Valley under surface irrigation and old land (Eid et al., 1994 and Khalil et al., 2009). Furthermore, the damage that climate change could do to wheat productivity is expected to be higher under soils with low fertility. Changes in yield behavior in relation to shifts in climate can become critical for the livelihoods and income of farmers. An increasing probability of low returns as a consequence of the more frequent occurrence of adverse conditions could prove dramatic for farmers operating at the limit of economic stress, especially for farmers cultivating low fertility soils. Under the projected climate change, extra damage is expected to occur to the yield of cultivated crops in these areas as a result of deterioration in the qulity and productivity of soil.

Crop simulation models can be used to assess the likely impact of climate change on grain yield and yield variability. These crop models must accurately predict several key characteristics over a wide range of climatic conditions, such as timing of flowering and physiological maturity, through correct descriptions of phenological responses to temperature and day length. Furthermore, accumulation of yield needs to be predicted by accurately predicting the development and loss of leaf area and, therefore, a crop's ability to intercept radiation, accumulate biomass, 
and partition it to harvestable parts such as grain. It is also necessary to accurately predicted crop water use (evapotranspiration) and extraction of soil water by plants roots (Richter and Semenov, 2005). CropSyst (Stockle et al., 1994) is one of these models that could be used along with a set of daily weather data spanning a reasonable number of years to assess the impact of climate change on agriculture. The application of such models allows the simulation of many possible climate change scenarios from only a few experiments for calibration.

In Egypt, El-Bustan area, a new reclaimed land located in the west of the Nile Delta, is a sandy soil with low organic matter and high water infiltration rate. The appropriate irrigation system to be used in this type of soil is drip and sprinkler irrigation. Wheat yield in El-Bustan area is 10\% lower than the wheat yield grown on clay soil in the same governorate (MALR, 2009). Under the projected climate change, extra damage in yield reduction is expected to occur from cultivated crops in these areas as a result of deterioration in soil productivity. Therefore, adaptation options should be developed in order to improve crop yield under the current and future climate. In sandy soil and under sprinkler irrigation, fertigation serves as improved management practices to reduce vulnerability of crops to climate change. Hoffman et al., (1992) defined fertigation as the application of fertilizer via an irrigation system by injecting it into the water flows through the system.
Ouda et al., (2010) stated that using chemigation for wheat grown under sprinkler irrigation increases wheat yield by $24 \%$, compared with traditional application of fertilizers.

The objectives of this research were: (I) to asses the effect of fertigation on wheat yield grown in sandy soil, and (ii) to use CropSyst model to simulate wheat yield under two climate change scenarios.

\section{Materials and methods}

\subsection{The field experiments}

Two field experiments were conducted at Aly Mobarak experimental farm in the South Tahrir Research station, Egypt, during the growing seasons of 2008/09 and 2009/10. The experimental site was a newly reclaimed sandy soil of El-Bustan area at the west of Nile delta. It is situated at an altitude of $6.7 \mathrm{~m}$ above mean sea level and is intersected by $3102 \mathrm{~N}$ latitude and $3028 \mathrm{E}$ longitude. The climate is characterized by a cool winter with a mean air temperature around $12^{\circ} \mathrm{C}$.Summer is hot with a mean air temperature that exceeds $32^{\circ} \mathrm{C}$ in June, July and August and mean relative humidity of about $70 \%$ during day time for these months. The scarce amounts of water coming from rainfall do not contribute to water requirements of winter crops. Weather data for the experimental site during the growing seasons of 2008/09 and 2009/10 are presented in Table (1). 
Table 1. Monthly mean maximum temperature (Tmax.), mean minimum temperature (Tmin.), relative humidity (RH), rainfall and pan evaporation (E pan) at the experimental site in 2008/09 and 2009/10 growing seasons.

\begin{tabular}{llccccc}
\hline & Month & Max. $\mathbf{T}^{\mathbf{0}} \mathbf{C}$ & Min. $\mathbf{T}^{\mathbf{0}} \mathbf{C}$ & RH \% & Rainfall $\mathbf{~ m m}$ & E pan mm \\
\hline $2008 / 09$ & November & 24.2 & 15.9 & 68 & 0 & 2.4 \\
& December & 21.0 & 12.2 & 71 & 0 & 2.2 \\
& January & 17.7 & 8.5 & 73 & 10 & 2.8 \\
& February & 18.9 & 8.8 & 74 & 7 & 3.0 \\
& March & 25.6 & 12.7 & 67 & 0 & 3.3 \\
& April & 27.6 & 14.3 & 66 & 0 & 4.4 \\
\hline $2009 / 10$ & November & 26.9 & 11.4 & 58 & 0 & 5.1 \\
& December & 24.1 & 11.4 & 65 & 0 & 3.6 \\
& January & 22.7 & 11.4 & 68 & 0 & 2.2 \\
& February & 24.2 & 12.1 & 67 & 15 & 2.6 \\
& March & 23.4 & 12.9 & 58 & 0 & 1.9 \\
& April & 29.6 & 11.8 & 67 & 0 & 2.2 \\
\hline
\end{tabular}

The experiments were laid out in a split- plot design with four replications. There were eight treatments consisting of combinations of four irrigation water amounts as main plots and two fertilizer application periods, through the irrigation water (fertigation), as subplots. The control treatment was designed to represent a 'typical' wheat irrigation regime, with fertilizer application broadcast on the field as used by the growers in the area of study $\left(\mathrm{I}_{0}\right)$. The fertegation treatments were: Irrigation water amount of 1.20 ETc with fertilizer application for a period equal to $80 \%$ of the irrigation time $\left(\mathrm{I}_{1}\right)$, irrigation amount of $1.20 \mathrm{ETc}$ with fertilizer application for a period equal to $60 \%$ of the irrigation time $\left(\mathrm{I}_{2}\right)$, irrigation amount of $1.00 \mathrm{ETc}$ with fertilizer application for a period equal to $80 \%$ of the irrigation time $\left(\mathrm{I}_{3}\right)$, irrigation amount of $1.00 \mathrm{ETc}$ with fertilizer application for a period equal to $60 \%$ of the irrigation time $\left(\mathrm{I}_{4}\right)$, Irrigation amount of $0.80 \mathrm{ETc}$ with fertilizer application for a period equal to $80 \%$ of the irrigation time $\left(\mathrm{I}_{5}\right)$, irrigation amount of $0.80 \mathrm{ETc}$ with fertilizer application for a period equal to $60 \%$ of the irrigation time $\left(\mathrm{I}_{6}\right)$, irrigation amount of $0.60 \mathrm{ETc}$ with fertilizer application for a period equal to $80 \%$ of the irrigation time $\left(\mathrm{I}_{7}\right)$ and irrigation amount of 0.6 ETc with fertilizer application for a period equal to $60 \%$ of the irrigation time $\left(\mathrm{I}_{8}\right)$.

Wheat (Giza 168) was planted on the $25^{\text {th }}$ of November for both growing seasons. Irrigation water was applied each four days by using a solid-set sprinkler system. The rotary sprinkler (type Rc160) of 0.87 to $1.23 \mathrm{~m}^{3} / \mathrm{hr}$ discharge at 2.10 to 2.5 bars nozzle pressure, with spacing of $9 * 7$ meters between laterals and sprinklers. A differential pressure tank was connected to the sprinkler irrigation system to inject fertilizer via irrigation water. The fertigation rate was determined according to irrigation system operation water supply, concentration of the fertilizer element in the stock solution and the discharge of the fertigator. Nitrogen fertilizer was added in the form of ammonium nitrate in the rate of $400 \mathrm{~kg} / \mathrm{ha}$. Potassium sulfate was added at the rate of $100 \mathrm{~kg} / \mathrm{ha}$. Phosphorus was added in the form of phosphoric acid $(60 \%)$ at the rate of $125 \mathrm{~kg} / \mathrm{ha}$. 
Evaporation data were collected on a daily basis from a standard class A pan evaporation tank located near the experimental field. Irrigation amounts were calculated according to evaporation pan records (Allen et al., 1998), using the equation:

$$
\mathrm{I}=\mathrm{A} * \mathrm{Ep} * \mathrm{Kpc}
$$

Where I = amount of irrigation water, $\mathrm{A}=$ ratio of depth of irrigation water applied to the cumulative evaporation, $\mathrm{Ep}=$ the cumulative evaporation amount for considering irrigation intervals and $\mathrm{Kpc}=$ coefficient (including pan coefficient $\mathrm{Kp}$, crop coefficient $\mathrm{Kc}$ and application efficiency).

Crop consumptive water use was estimated by the method of soil moisture depletion according to Majumdar (2002), as follows:

$\mathrm{WCU}=\sum_{\mathrm{i}=1(02-01) / 100 * \mathrm{Bd} * \mathrm{Di}}^{\mathrm{n}}$
Where: $\mathrm{WCU}=$ crop consumptive water use $(\mathrm{cm})$ from the effective root zone $(60 \mathrm{~cm}), \theta 2=$ soil moisture percentage by weight after irrigation, $\theta 1=$ soil moisture percentage by weight before the following irrigation, $\mathrm{Bd}=$ bulk density in $\left(\mathrm{g} / \mathrm{cm}^{3}\right)$ of the $\mathrm{i}^{\text {th }}$ soil layer, $D_{i}=$ depth of the $i^{\text {th }}$ layer of soil and $n=$ number of soil layers in the root zones.

Soil moisture content from 0-20, 20-40 and 40-60 $\mathrm{cm}$ depths was measured by the gravimetric method for each plot before sowing, straight after harvest and just before and after irrigation event. Soil moisture measured by gravimetric method (weight basis) was converted into volumetric proportion by multiplying by bulk density.

Some physical and chemical properties of the experimental site are shown in Table (2). Chemical and physical soil analyses were conducted by the standard methods described by Tan (1996). Chemical analysis of the irrigation water indicated that electrical conductivity (EC) was $0.50(\mathrm{dS} / \mathrm{m})$ at $25^{\circ} \mathrm{C}$ and $\mathrm{pH}$ value was 7.55.

Table 2. Some soil physical and chemical properties of the experimental site

\begin{tabular}{|c|c|c|c|}
\hline \multirow{2}{*}{ Soil properties } & & \multicolumn{2}{|c|}{ Soil depth (cm) } \\
\hline & & $0-30$ & $30-60$ \\
\hline \multicolumn{4}{|l|}{ Particle size distribution } \\
\hline Sand & $\%$ & 90.75 & 90.25 \\
\hline Silt & $\%$ & 3.75 & 3.95 \\
\hline Clay & $\%$ & 5.50 & 5.80 \\
\hline Texture & & Sandy & Sandy \\
\hline Bulk density & $\mathrm{mg} \mathrm{m}^{-3}$ & 1.58 & 1.76 \\
\hline Field capacity & $\% \mathrm{w} / \mathrm{w}$ & 11.25 & 9.35 \\
\hline Permanent wilting point & $\% \mathrm{w} / \mathrm{w}$ & 5.45 & 4.60 \\
\hline Available water & $\%$ & 5.80 & 4.75 \\
\hline $\mathrm{pH}(1: 2.5)$ & & 9.13 & 9.38 \\
\hline EC, soil past extract & ds $m^{-1}$ & 0.35 & 0.30 \\
\hline \multicolumn{4}{|l|}{ Soluble cations } \\
\hline $\mathrm{Ca}^{++}$ & meq $L^{-1}$ & 1.23 & 1.25 \\
\hline $\mathrm{Mg}^{++}$ & meq $L^{-1}$ & 0.54 & 0.49 \\
\hline
\end{tabular}


Continued...

\begin{tabular}{llcc}
\hline \multirow{2}{*}{ Soil properties } & & \multicolumn{2}{c}{ Soil depth (cm) } \\
\cline { 3 - 4 } $\mathrm{Na}^{+}$ & & $\mathbf{0 - 3 0}$ & $\mathbf{3 0 - 6 0}$ \\
$\mathrm{K}^{+}$ & $\mathrm{meq} \mathrm{L}^{-1}$ & 1.56 & 1.61 \\
Soluble anions & meq L-1 & 0.17 & 0.15 \\
$\mathrm{CO}_{3}^{--}$ & & & \\
$\mathrm{HCO}_{3}^{-}$ & meq L-1 & 0.00 & 0.00 \\
$\mathrm{Cl}^{-}$ & meq L-1 & 1.10 & 1.07 \\
$\mathrm{SO}_{4}^{--}$ & meq L-1 & 1.73 & 1.74 \\
\hline
\end{tabular}

Agronomic measurements were done for root and above ground biomass weight at 50 and 75 days after planting. Maximum leaf area was measured and the leaf area index (LAI) was calculated by the following equation:

\section{$\mathrm{LAI}=$ Leaf area per plant/plant ground area}

Where: plant ground area is the area of land occupied by the plant (equal distance between the plant* distance between ridges).

Harvest was done on the $14^{\text {th }}$ of April during the two growing seasons. Wheat grain and biological yield were measured at harvest and harvest index was calculated. These measurements were used to check the accuracy of the CropSyst model in predicting the final wheat yield.

\subsection{CropSyst model}

\section{Model description}

The objective of the Crop model (Stockle et al., 1994) is to serve as an analytical tool to study the effect of cropping systems and management on crop productivity and the environment. For this purpose, CropSyst simulates soil water budget, soil-plant nitrogen budget, crop phenology, crop canopy and root growth, biomass production, crop yield, residue production and decomposition, soil erosion by water, and pesticide fate, which are affected by weather, soil characteristics, crop characteristics, and cropping system management options which include crop rotation, variety selection, irrigation, nitrogen fertilization, pesticide applications, soil and irrigation water salinity, tillage operations, and residue management.

The water budget in the model includes rainfall, irrigation, runoff, interception, water infiltration and redistribution in the soil profile, crop transpiration, and evaporation. The nitrogen budget in CropSyst includes nitrogen application, nitrogen transport, nitrogen transformations, ammonium absorption and crop nitrogen uptake. The calculation of daily crop growth, expressed as biomass increase per unit area, is based on a minimum of four limiting factors; namely, light, temperature, water and nitrogen. Pala et al. (1996) suggested that minor adjustments of some of these parameters, accounting for cultivar-specific differences, are desirable whenever suitable experimental information is available. Details on the technical aspects and use of the CropSyst model have been reported elsewhere (Stockle et al., 1994).

\section{Model calibration}

After each growing season, input files required by CropSyst model for El-Bustan location and wheat crop were prepared and used to run the model. For each treatment 
one management file was prepared to represent each irrigation treatment. The date of each phenological stage was used to calculate growing degree days for that stage. Total biomass, grain yield, total and seasonal evapotranspiration, computed from the soil-moisture measurements from all the treatments, were used for model calibration. The values of the crop input parameters were either taken from the CropSyst manual (Stockle et al., 1994) or set to the values observed in the experiments. The calibration consisted of slight adjustments of selected crop input parameters to reflect reasonable simulations. These adjustments were between values that were either typical for the crop species or known from previous experiences with the model.

\subsection{Goodness of fit}

To test the goodness of fit between the measured and predicted data, percent difference between measured and predicted values of grain yield and biological yield in each growing season was calculated, in addition to consumptive use. Furthermore, root mean square error which describes the average difference between measured and predicted value were calculated (Jamieson et al.,1998).Also, Willmott index of agreement was calculated, which take a value between 0.0-1.0 and 1.0 means perfect fit (Willmott, 1981).

\subsection{Climate change scenarios}

In this work, the HadCM3, which is a coupled atmosphere-ocean general circulation model (AOGCM) developed at the Hadley Centre for Climate Prediction and Research (United Kingdom) was used (Gordon et al., 2000 and Pope et al., 2000) as it is considered more significant and more sophisticated than earlier versions. This model has a spatial resolution of 2.5 x 3.75 (latitude by longitude). HadCM3 provides information about climate change all over the entire world during the $21^{\text {st }}$ century and presents information about three times slices: 2020s, 2050s, and 2080s. In order to provide information on possible changes in the world climate, the climate change models are forced to consider future scenarios. The IPCC (Nakicenvic et al., 2000) has developed emission scenarios known as SRES (Special Report on Emission Scenarios). The four SRES scenarios combined two sets of divergent tendencies: one set varies between strong economic values and strong environmental values, while the other set varies between increasing globalization and increasing regionalization (IPCC-TGCIA, 1999). Two climate change scenarios were considered in this study: A2 and B2. These selected two scenarios take into consideration rise in global annual mean temperature by 3.09 and $2.16^{\circ} \mathrm{C}$, respectively, $\mathrm{CO}_{2}$ concentration 834 and $601 \mathrm{ppm}$, respectively and global mean sea level rise 62 and $52 \mathrm{~cm}$, respectively. As the resolution of the model is very big, simple interpolation techniques of these percentages have been applied to fit the station site. Data were downloaded in GRIB format from the IPCC Data Distribution Centre web site. The GRBCONV program source code can be found at the following web site: [http://www/dkrz. de/ipcc/ddc/html/HadleyCM3/hadcm3. html].

The GRBCONV program was used to convert the data files from GRIB format to the more conventional ASCII. The download site does not offer the option to subset the data based on an area of interest. Therefore a custom program was used to extract the data for the region of interest. HadCM3 variables were monthly precipitation, solar radiation, minimum and maximum temperatures.

A2 and B2 climate change scenarios were used to run the CropSyst model to predict wheat yield and consumptive use in the year of 2050s. The effect of climate change on each of the two growing seasons will be discussed separately where each season would be a representation of the growing season of the year of 2050. 


\section{Results and discussion}

\subsection{Wheat yield, irrigation amounts and water use} efficiency

Water use efficiency was the lowest under farmer irrigation, whereas the applied irrigation amount was the highest $(650 \mathrm{~mm})$, compared to the irrigation treatments in both growing seasons (Table3). The highest water use efficiency was obtained when irrigation was applied using 0.8 of ETc with fertigation application in $80 \%$ of application time, i.e. 16.86 and $15.90 \mathrm{~kg} /$ $\mathrm{mm}$ for the first and second seasons respectively. The results in Table (3) showed that the highest yield was obtained under irrigation application using 1.2 of ETc with fertigation application in $80 \%$ of application time in both growing seasons.

Table 3. Grain yield, irrigation amounts and water use efficiency (WUE) for wheat grown in 2008/09 and 2009/10 growing seasons

\begin{tabular}{lcccccc}
\hline $\begin{array}{l}\text { Irrigation } \\
\text { treatments }\end{array}$ & \multicolumn{3}{c}{$\mathbf{1}^{\text {st }}$ growing season } & \multicolumn{3}{c}{$\mathbf{2}^{\text {nd }}$ growing season } \\
\cline { 2 - 6 } & $\begin{array}{c}\text { Grain yield } \\
\left(\mathbf{t o n} \mathbf{h a}^{-1}\right)\end{array}$ & $\begin{array}{c}\text { Irrigation } \\
(\mathbf{m m})\end{array}$ & $\begin{array}{c}\text { WUE } \\
\left(\mathbf{k g}^{-1} \mathbf{~ m m}\right)\end{array}$ & $\begin{array}{c}\text { Grain yield } \\
\left(\mathbf{t o n}_{\mathbf{h a}} \mathbf{- 1}\right)\end{array}$ & $\begin{array}{c}\text { Irrigation } \\
(\mathbf{m m})\end{array}$ & $\begin{array}{c}\text { WUE } \\
\left(\mathbf{k g}^{-1} \mathbf{~ m m}\right)\end{array}$ \\
\hline Io & 4.72 & 650 & 7.25 & 4.38 & 660 & 6.58 \\
I1 & 6.85 & 477 & 14.34 & 6.11 & 481 & 12.66 \\
I2 & 6.56 & 477 & 13.69 & 5.85 & 481 & 12.08 \\
I3 & 6.70 & 436 & 15.30 & 6.07 & 419 & 14.44 \\
I4 & 6.58 & 436 & 15.07 & 5.66 & 419 & 13.39 \\
I5 & 6.13 & 362 & 16.86 & 5.68 & 356 & 15.90 \\
I6 & 5.88 & 362 & 16.14 & 5.07 & 356 & 14.21 \\
I7 & 5.02 & 314 & 15.97 & 4.29 & 294 & 14.52 \\
I8 & 4.96 & 314 & 15.67 & 4.23 & 294 & 14.35 \\
\hline
\end{tabular}

\subsection{Model calibration}

Wheat grain yield

CropSyst model showed good agreement between measured and predicted values of wheat grain yield (Table 4). Low percentage of difference between observed and predicted values was obtained, as well as low root mean square error. Furthermore, the value of Willmott index which was close to 1 indicated good agreement. Several publications highlighted the accuracy of the model, such as Benli et al., (2007) who indicated that the model prediction showed low RMSE. Furthermore, Benli et al., (2007) stated that high Willmott index of agreement was obtained with a value of 0.98, which is similar to what is shown in Table (4). 
Table 4. Measured versus predicted wheat grain yield (ton ha ${ }^{-1}$ ) grown in 2008/09 and 2009/10 growing seasons

\begin{tabular}{lcccccc}
\hline \multirow{2}{*}{ Irrigation } & \multicolumn{3}{c}{$\mathbf{1}^{\text {st }}$ growing season } & \multicolumn{3}{c}{$\mathbf{2}^{\text {nd }}$ growing season } \\
\cline { 2 - 7 } & Measured & Predicted & PC\% & Measured & Predicted & PC\% \\
\hline $\mathrm{I}_{0}$ & 4.72 & 4.71 & 0.2 & 4.38 & 4.34 & 0.9 \\
$\mathrm{I}_{1}$ & 6.85 & 6.84 & 0.2 & 6.11 & 6.09 & 0.3 \\
$\mathrm{I}_{2}$ & 6.56 & 6.53 & 0.5 & 5.85 & 5.81 & 0.7 \\
$\mathrm{I}_{3}$ & 6.70 & 6.67 & 0.5 & 6.07 & 6.05 & 0.3 \\
$\mathrm{I}_{4}$ & 6.58 & 6.57 & 0.2 & 5.66 & 5.61 & 0.9 \\
$\mathrm{I}_{5}$ & 6.13 & 6.11 & 0.3 & 5.68 & 5.66 & 0.4 \\
$\mathrm{I}_{6}$ & 5.88 & 5.85 & 0.5 & 5.07 & 5.06 & 0.2 \\
$\mathrm{I}_{7}$ & 5.02 & 5.00 & 0.1 & 4.29 & 4.27 & 0.5 \\
$\mathrm{I}_{8}$ & 4.96 & 4.92 & 0.4 & 4.23 & 4.22 & 0.2 \\
$\mathrm{RMSE}$ & & 0.30 & & & 0.30 & \\
$\mathrm{WI}$ & & 0.98 & & & 0.97 & \\
\hline
\end{tabular}

$\mathrm{PC} \%=$ percentage of difference between observed and predicted values.

RMSE $=$ root mean square error.

$\mathrm{WI}=$ Willmott index.

\section{Wheat biological yield}

The model over-predicted the values of wheat biological yield under some irrigation treatments, where the percentage of change between observed and predicted values were between $+2.61 \%$ to $-2.29 \%$ in the first growing season (Table 5). In the second growing season, the value ranged between $-3.91 \%$ and $+0.81 \%$.
Root mean square error was 0.39 and 0.34 ton/ha for the first and the second seasons, respectively. In addition, Willmott index of agreement was close to 1, i.e. 0.97 and $0.98 \%$. Benli et al., (2007), stated that RMSE represented $21 \%$ of the observed average, whereas Willmott index of agreement between the observed and simulated biomass was 0.76 , which means that is reasonably close to 1 . 
Table 5. Measured versus predicted wheat biological (ton/ha) yield grown in 2008/09 and 2009/10 growing seasons

\begin{tabular}{lcccccc}
\hline \multirow{2}{*}{ Treatments } & \multicolumn{3}{c}{$\mathbf{1}^{\text {st }}$ growing season } & \multicolumn{3}{c}{$\mathbf{2}^{\text {nd }}$ growing season } \\
\cline { 2 - 6 } & Measured & Predicted & PC \% & Measured & Predicted & PC \% \\
\hline $\mathrm{I}_{0}$ & 27.04 & 27.75 & +2.61 & 25.71 & 25.55 & -0.62 \\
$\mathrm{I}_{1}$ & 26.43 & 26.31 & -0.45 & 27.14 & 26.46 & -2.51 \\
$\mathrm{I}_{2}$ & 24.92 & 25.13 & +0.84 & 26.28 & 26.42 & +0.53 \\
$\mathrm{I}_{3}$ & 24.38 & 24.73 & +1.44 & 21.21 & 20.87 & -1.60 \\
$\mathrm{I}_{4}$ & 25.00 & 25.27 & +1.08 & 22.28 & 22.46 & +0.81 \\
$\mathrm{I}_{5}$ & 23.16 & 22.63 & -2.29 & 20.09 & 20.21 & +0.60 \\
$\mathrm{I}_{6}$ & 22.00 & 21.69 & -1.41 & 18.96 & 18.73 & -1.21 \\
$\mathrm{I}_{7}$ & 19.00 & 19.29 & +1.54 & 16.57 & 16.44 & -0.78 \\
$\mathrm{I}_{8}$ & 17.00 & 16.97 & -0.18 & 14.82 & 14.24 & -3.91 \\
$\mathrm{RMSE}$ & & 0.39 & & & 0.34 & \\
WI & 0.97 & & & 0.98 & \\
\hline
\end{tabular}

$\mathrm{PC} \%=$ percentage of difference between observed and predicted values.

$\mathrm{RMSE}=$ root mean square error.

$\mathrm{WI}=$ Willmott index .

\section{Wheat Consumptive use}

The obtained results from the calibration of CropSyst model for consumptive use revealed that the percentage of change between measured and predicted values was less than $1.5 \%$ in both growing seasons (Table 6). Root mean square error was 2.80 and $2.23 \mathrm{~mm}$ and Willmott index of agreement was close to 1 . Similar results were obtained by Wang et al., (2006), where RMSE was $0.07 \mathrm{~mm}$ for evapotranspiration and Punnkuk et al., (1998), where it was $0.05 \mathrm{~mm}$ when CropSyst was used to predict evapotranspiration. Benli et al., (2007) stated that CropSyst model predicted consumptive use reasonably well. The RMSE values were $11 \%$ of the average observed ET and the Willmo$\mathrm{tt}$ index of agreement (0.91) was reasonably close to 1 .

Our results showed that CropSyst model was able to predict yield and consumptive use of wheat grown in sandy soil under the Egyptian conditions (Tables 3,4 and 6). One of the benefits of using CropSyst model is that it can give an insight to processes that took place during wheat growth in the growing season which was difficult to be measured in the field. The good agreement between measured and predicted values of wheat grain and biological yield as well as consumptive use implied that the model worked sufficiently well to warrant the exploration of the effect of climate change scenarios. 
Table 6. Measured versus predicted wheat consumptive use (mm) grown in 2008/09 and 2009/10 growing seasons

\begin{tabular}{lcccccc}
\hline \multirow{2}{*}{ Treatments } & \multicolumn{3}{c}{$\mathbf{1}^{\text {st }}$ growing season } & \multicolumn{3}{c}{$\mathbf{2}^{\text {nd }}$ growing season } \\
\cline { 2 - 6 } & Measured & Predicted & PC \% & Measured & Predicted & PC \% \\
\hline $\mathrm{I}_{0}$ & 422.00 & 418.88 & 0.7 & 432.67 & 430.80 & 0.4 \\
$\mathrm{I}_{1}$ & 371.10 & 366.62 & 1.2 & 378.80 & 377.31 & 0.4 \\
$\mathrm{I}_{2}$ & 371.10 & 368.74 & 0.6 & 378.80 & 377.05 & 0.5 \\
$\mathrm{I}_{3}$ & 325.40 & 322.00 & 1.0 & 326.24 & 324.86 & 0.4 \\
$\mathrm{I}_{4}$ & 325.00 & 323.82 & 0.4 & 326.24 & 324.60 & 0.5 \\
$\mathrm{I}_{5}$ & 275.26 & 273.44 & 0.7 & 287.00 & 285.35 & 0.6 \\
$\mathrm{I}_{6}$ & 275.26 & 274.51 & 0.3 & 287.00 & 285.27 & 0.6 \\
$\mathrm{I}_{7}$ & 234.30 & 231.28 & 1.3 & 233.00 & 229.74 & 1.4 \\
$\mathrm{I}_{8}$ & 234.30 & 232.38 & 0.8 & 233.00 & 229.82 & 1.4 \\
$\mathrm{RMSE}$ & & 2.80 & & & 2.23 & \\
$\mathrm{WI}$ & 0.99 & & & 0.99 & \\
\hline
\end{tabular}

$\mathrm{PC} \%=$ percentage of difference between observed and predicted values.

RMSE $=$ root mean square error.

$\mathrm{WI}=$ Willmott index.

\section{Effect of climate change}

Reduction in wheat yield under A2 climate change scenario was higher than the reduction under B2 climate change scenario (Table 7). Furthermore, the reduction in the yield was higher in the second growing season than in the first growing season.

The highest percentage of yield reduction was obtained for farmer irrigation and irrigation using 0.6 of ETc with fertigation application in $60 \%$ of application time. The farmer irrigation was associated with high applied irrigation water in both growing seasons and low water use efficiency under current climate conditions (Table 3). Moreover, the high reduction in the yield for farmer irrigation could be a result of leaching nutrients away from root zone and oxygen deficiency (Ouda et al., 2008). Similar results were obtained by Ouda et al., (2010). Irrigation using 0.6 of ETc with fertigation application in $60 \%$ of application time treatment was coupled with low applied irrigation water (Table 2). This result emphasis proper management of irrigation water under current climate conditions, which could reduce yield losses under climate change conditions.

The results in Table (7) implied that climate change altered the natural growing conditions for wheat, which resulted in biotic stress, such as heat and water stresses that wheat plants exposed to. Exposing wheat plants to high moisture stress depressed seasonal consumptive use and grain yield (El-Kalla $e t$ al., 1994 and Khater et al., 1997). During vegetative growth, phyllochron decreases in wheat under water stress and leaves become smaller, which could reduce leaf area index (Gardner, et al., 1985) and reduce the number of reproductive tillers, in addition to limit their contribution to grain yield (Mosaad et al., 1995). Furthermore, water stress occurs during grain growth could have a strong effect on final yield compared 
with stress occurred during other stages (Hanson and Nelson, 1980). High temperature reduces numbers of tillers and spikelet initiation and development rates (McMaster, 1997). Moreover, high temperature during flowering causes pollen sterility (Saini and Aspinall, 1982) and reduces number of kernels per head, if it occurred during early spike development (Kolderup, 1979). The duration of grain filling is also reduced under heat stress (Sofield et al., 1977), as well as growth rates with a net effect of lower final kernel weight (Bagga and Rawson 1977; McMaster, 1997).

The lowest percentage yield reduction was obtained for irrigation using amount of 1.0 of ETc with fertigation application in $80 \%$ of application time, i.e.
28 and $27 \%$ under A2 in the first and second season, respectively. Under B2 climate change, the percentage of yield reduction was 24 for both growing seasons, respectively (Table 7). These results implied that fertigation application increased water and fertilizer use efficiency and prevents $\mathrm{N}$ and $\mathrm{K}$ leaching in the sandy soil of the experimental site. Water and fertilizer use efficiencies increased yield under current climate conditions (Table 3) and help wheat plants to withstand the stressful conditions of climate change (Table 7). Therefore, it is recommended to irrigate wheat using amount of 1.0 of ETc with fertigation application in $80 \%$ of application time to reduce yield losses.

Table 7. Percentage of reduction in wheat yield as affected by the two climate change scenarios in both growing seasons

\begin{tabular}{lllll}
\hline \multirow{2}{*}{ Treatments } & \multicolumn{2}{c}{$\mathbf{1}^{\text {st }}$ growing season } & \multicolumn{2}{c}{$\mathbf{2}^{\text {nd }}$ growing season } \\
\cline { 2 - 5 } & A2 & B2 & A2 & B2 \\
\hline $\mathrm{I}_{0}$ & 40 & 38 & 38 & 35 \\
$\mathrm{I}_{1}$ & 31 & 29 & 29 & 24 \\
$\mathrm{I}_{2}$ & 32 & 29 & 30 & 27 \\
$\mathrm{I}_{3}$ & 28 & 24 & 27 & 24 \\
$\mathrm{I}_{4}$ & 29 & 25 & 27 & 25 \\
$\mathrm{I}_{5}$ & 36 & 32 & 31 & 30 \\
$\mathrm{I}_{6}$ & 37 & 33 & 34 & 32 \\
$\mathrm{I}_{7}$ & 39 & 34 & 35 & 34 \\
$\mathrm{I}_{8}$ & 40 & 37 & 38 & 37 \\
\hline
\end{tabular}

\section{Water use efficiency}

The anticipated climate change condition is expected not only to decrease crops yield, but also to lessen water use efficiency. Water use efficiency was reduced under both A2 and B2 climate change scenarios, compared to its corresponding values under current climate conditions (Table 8). However, the reduction was higher under A2, compared to B2. The highest water use efficiency in the first growing season was obtained with irrigation amount of 1.0 of ETc with fertigation application in $80 \%$ of application time, i.e. 10.94 and $11.70 \mathrm{~kg} / \mathrm{mm}$ under both A2 and B2 scenarios, respectively (Table 8). Regarding the second growing season, irrigation with an amount of 0.8 of ETc and fertigation application in $80 \%$ of application time resulted in high- 
est water use efficiency, i.e. 10.98 and $11.21 \mathrm{~kg} / \mathrm{mm}$ under both A2 and B2 scenarios. Therefore, it is recommended to irrigate wheat grown in sandy soil with an amount of either 1.0 or 0.8 of ETc with fertigation application in $80 \%$ of application time to reduce yield losses and increase water use efficiency. Similar results were obtained by Khalil et al., (2009), where water use efficiency was reduced under climate change.

Table 8. Water use efficiency $\left(\mathrm{kg}^{-1} \mathrm{~mm}\right)$ under current climate and climate change conditions for wheat in both growing seasons (A2 and B2)

\begin{tabular}{lcccccc}
\hline \multirow{2}{*}{$\begin{array}{l}\text { Irrigation } \\
\text { Treatments }\end{array}$} & \multicolumn{2}{c}{$\mathbf{1}^{\text {st }}$ growing season } & \multicolumn{3}{c}{$\mathbf{2}^{\text {nd }}$ growing season } \\
\cline { 2 - 7 } & Current climate & $\mathbf{A 2}$ & $\mathbf{B 2}$ & Current climate & $\mathbf{A 2}$ & $\mathbf{B 2}$ \\
\hline $\mathrm{I}_{0}$ & 7.25 & 4.32 & 4.48 & 6.58 & 4.06 & 4.29 \\
$\mathrm{I}_{1}$ & 14.34 & 9.94 & 10.17 & 12.66 & 8.98 & 9.63 \\
$\mathrm{I}_{2}$ & 13.69 & 9.33 & 9.75 & 12.08 & 8.42 & 8.84 \\
$\mathrm{I}_{3}$ & 15.30 & 10.94 & 11.70 & 14.44 & 10.48 & 10.93 \\
$\mathrm{I}_{4}$ & 15.07 & 10.76 & 11.38 & 13.39 & 9.81 & 10.02 \\
$\mathrm{I}_{5}$ & 16.86 & 10.79 & 11.46 & 15.90 & 10.98 & 11.21 \\
$\mathrm{I}_{6}$ & 16.14 & 10.24 & 10.80 & 14.21 & 9.38 & 9.63 \\
$\mathrm{I}_{7}$ & 15.97 & 9.71 & 10.48 & 14.52 & 9.39 & 9.56 \\
$\mathrm{I}_{8}$ & 15.67 & 9.39 & 9.87 & 14.35 & 8.91 & 9.08 \\
\hline
\end{tabular}

\section{Conclusion}

This study was conducted in Egypt to assess the effect of using different fertigation treatments on wheat grown in sandy soil and under sprinkler irrigation, and to simulate the effect of climate change on wheat yield. The real challenge under climate change conditions is to use adaptation strategies, which are improved agricultural management practices, to reduce the damage caused by climate change on the yield of the growing crops. Plant breeders could use the results of the application of the simulation models to help in the development of new varieties adapted to climate change. Wheat breeders will need to focus on overcoming heat stress rather than improving drought tolerance as a result of climate change. Moreover, breeding wheat varieties with high water use efficiency is also a very important goal to be achieved.

\section{References}

Allen, R. G., Pereira, L. S., Raes, D. Smith, M. 1998. Crop evapotranspiration: Guideline for computing crop water requirements. FAO, №56.

Bagga, A., Rawson, I. M. 1977. Contracting responses of morphologically similar wheat varieties to temperature appropriate to warm temperature climates with hot summers: A study in controlled environment. Aust. J. Agric. Res. 40:965-980.

Benli, B., Pala, M., Stockle, C.,Oweis, T. 2007. Assessment of winter wheat production under early sowing with supplemental irrigation in a cold highland environment using CropSyst simulation model. Agric. Water Mang.3:45-54.

Church, J. A., White, N. J. 2006. A $20^{\text {th }}$ century acceleration in global sea-level rise. Geophysical Research Letters, 33, L01602. 
Eid, H. M., Anton, N. A., Tarrad, A. M. 1994. Comparative study on Egyptian wheat varieties and their response to high temperatures. Annals of Agric. Sci. Moshtohor Vol. 32 (1) 143-154.

El-Kalla, S.E., Leilah, A.A., Basiony, A.H., Hussien S.M. 1994. Effect of Irrigation and foliar nutrition treatments on growth and yield of some wheat cultivars under El-Arish area condition. $6^{\text {th }}$ conf. Agron., Fac. Agric., Al-Azhar Uni., Egypt.

Gardner, F.P., Pearce, R.B., Mitchell, R.L. 1985. Physiology of crop plants. Iowa State

University Press. Ames.

Gordon, C., Cooper, C.A., Senior, H., Banks, J., Gregory, M., Johns, T. C., Mitchell, F.B., Wood, R.A. 2000. The simulation of sea surface temperature, sea ice extents and ocean heat transports in a version of the Hadley Centre coupled model without flux adjustments. Climate Dynamics (16):147168.

Hanson, A.D., Nelson E.C. 1980. The biology of crop production. New York Academic Press.

Hoffman, G. J., Howell T. A.,Solomon K. H. 1992. Management of farm irrigation system. ASAE Monograph No. 9. ASAE, USA. p. 1040.

IPCC. 2001: Summary for Policymakers: Climate Change 2001: The Scientific Basis, Contribution of Working Group I to the $3^{\text {rd }}$ Assessment Report of the Intergovernmental Panel on Climate Change. J. T. Houghton, Y. Ding, D. J. Griggs, M. Noguer, P. J. Van Der Linden, and D. Xioaosu, Cambridge University Press, Cambridge, 944pp.

IPCC-TGCIA. 1999. Guidelines on the use of Scenario Data for Climate Impact and Adaptation Assessment, Version 1. Prepared by Carter, T.R., Hulme M., and Lal. M. Intergovernmental Panel on Climate Change, task Group on Scenarios for Climate Impact Assessment. Cambridge University Press, Cambridge, 944p.
Jamieson, P.D., Porter, J. R., Goudriaan, J., Ritchie, J.T., Van Keulen, H., Stol. W. 1998. A comparison of the models AFRCWHEAT2, CERES-Wheat, Sirius, SUCROS2 and SWHEAT with measurements from wheat grown under drought. Field Crops Res. 55:23-44.

Khalil, F.A., Farag, H., Afandi, G. El., Ouda, S. A., 2009. Vulnerability and adaptation of wheat to climate change in Middle Egypt. $13^{\text {th }}$ Conference on Water Technology. Hurghada, Egypt. 12-15 March.

Khater, A.N, Abdel Maksoud, H.H., Eid, H.M. 1997. Response of some wheat cultivars and their water relations to different irrigation level in Middle Delta. Egypt, J. Appl. Sci.11(2):15-29.

Kolderup, I. 1979. Application of different temperatures in three growth phases of wheat. II. Effects on ear size and seed setting. Acta. Agric. Scand. 29:11-116.

Majumdar, D.K. 2002. Irrigation Water Management: Principles and Practice. $2^{\text {nd }}$ ed. Prentice-Hall of India, New Delhi- 110001.487p.

MALR.2009. Study of Important Indicators of Agricultural Statistics. Ministry of Agriculture and Land Reclamation, Egypt: Winter Crops Volume (1), No1170.

McMaster, G.S. 1997. Phonology, development, and growth of wheat (Triticum aestivum L.) shoot apex: A review. Advaces in Agron. 59:63-118.

Mosaad, M.G., Ortiz-Ferrara, G., Mahalak-Shmi, V. 1995. Tiller development and contribution to yield under different moisture regimes in two Triticum species. J. Agron. 174: 173-180.

Nakicenovic, N,; Alcamo, J., Davis, G., de Vries B.; Fenhann, J., Gaffin, S., Gregory, K., Grubler, A., Jung, T.Y., Kram, T., La Rovere, E.L., Michaelis, L.; Mori, S.; Morita, T.;Pepper, W.; Pitcher, H., Price, L, Raihi, K, Roehrl, A., Rogner, H., Sankovski, A., Schlesingger, M., Shukla, P., 
Smith, S., Swart, R, van Rooijen, S., N Victor and Z. Dadi. 2000. IPCC Special Report on Emission Scenarios Cambridge University Press, 599 P.

Ouda, S. A., Sayed, M., El Afandi G., Khalil, F.A. 2010. Developing an adaptation strategy to reduce climate change risks on wheat grown in sandy soil in Egypt. $10^{\text {th }}$ International Conference on Development of Dry lands. 12-15 December. Cairo, Egypt.

Ouda, S. A., Khalil, F. A., Abou Elenin, R., Shreif, M., Benli, B., Qadir, M. 2008. Using Yield-Stress model in irrigation management for wheat grown in Egypt. J. Appl. Bio. Sci. 2(1):57-65.

Pala, M., Stockle, C.S., Harris, H.C. 1996. Simulation of durum wheat (Triticum turgidum ssp Durum) growth under different water and nitrogen regimes in a Mediterranean environment using CropSyst. Agric. Sys. 51 (2), 147-163.

Pannkuk, C. D., Stockle, C.O., Papendick, R. I.1998. Evaluating CropSyst simulations of wheat management in a wheat-fallow region of the US Pacific Northwest. Agric. Syst. 57(2):121-133.

Pope, V. D., Gallani, M. L., Rowntree, P.R., Stratton. R.A. 2000. The impact of new physical parametrization in the Hadley Centre Climate ModelHadCM3. Climate Dynamics (16): 123-146.
Richter, G. M., Semenov, M. A. 2005. Modelling impacts of climate change on wheat yields in England and Wales: Assessing drought risks. Agricultural Systems 84(1): 77-97.

Saini, H. S., Aspinall, D. 1982. Sterility in wheat (Triticum aestivum L.) induced by water stress or high temperature: Possible mediation by abscisic acid. Aust. J. Plant Physio. 9:529-537.

Sofield, I. L., Evans, T. Wardlaw, I. F. 1977. The effect of temperature and light on grain filling in wheat. R. Soc. N. Z. Bull. 12:909-915.

Stockle, C. O., Martin, S., Campbell, S. 1994. CropSyst, a cropping systems model: water/nitrogen budgets and crop yield. Agricultural Systems. 46:335-359.

Tan K.H. 1996. Soil Sampling, Preparation and Analysis. Marcel Dekker, Inc. New York, p.391.

Wang, Z., Zhang, B., Xiao-yan, L., Song, K., Liu, D. Zhang. S. 2006. Using CropSyst to simulate spring wheat growth in Black Soil Zone of Northeast China. Pedoshere. 16(2):121-134.

Willmott, C.J. 1981. On the validation of models. Phys. Geogr. 2:184-194. 
